\title{
LEGAL POSITION OF FOREIGNERS IN CROATIAN HISTORY - PAST LESSONS FOR CURRENT IMMIGRATION PROBLEMS
}

\author{
Jelena Kasap, PhD, Assistant Professor
}

Josip Juraj Strossmayer University of Osijek, Faculty of Law

Stjepana Radića 13, Osijek, Croatia

jkasap@pravos.hr

\section{Višnja Lachner, PhD, Assistant Professor}

Josip Juraj Strossmayer University of Osijek, Faculty of Law

Stjepana Radića 13, Osijek, Croatia

vlachner@pravos.hr

\section{Nikol Žiha, PhD, Assistant Professor}

Josip Juraj Strossmayer University of Osijek, Faculty of Law

Stjepana Radića 13, Osijek, Croatia

nikolz@pravos.hr

\section{ABSTRACT}

The European Union has been exposed to very dynamic social changes for the last decade, and the issues of migration, asylum, and the protection of the legal position of foreigners have become some of the most vibrant areas within the EU political agenda, in particular within the activities of the European Parliament.

Relatively frequent migration policy changes within national legislation are the result of attempts to harmonize it with the recent EU acquis. In modern Croatian legislation, in accordance with the content of the applicable Aliens Act, there are visible attempts of legal balancing between the two dominant interests: the very extensive protection of social, political, economic, and other rights of immigrants and the security and protection of the national public policy. Nevertheless, understanding the legal position of foreigners in Croatian law demands consideration of various social and political factors and an extensive interpretation of the legal framework that has actively developed throughout history in our area.

Taking into account the growing importance of immigration policy for the territory of the Republic of Croatia, the aim of this article is to determine the legal position of foreigners in the domain of private and public law throughout different periods of Croatian legal history and, ultimately, by comparing the results with the contemporary situation, question their continuity and offer some lessons for current immigration problems.

Keywords: Croatian legal history, foreigners, integration, legal position, migration policy, personal rights 


\section{INTRODUCTION}

The specific geostrategic position of Croatia within Europe appears to be an intersection of migration flows throughout history. ${ }^{1}$ Although traditionally an emigration country, which, according to recent trends, seems to be a recurring pattern, there has been a change of perception such that the Croatian territory is no longer seen as exclusively emigrant. ${ }^{2}$ The issue of legal immigration, of which the historical aspect is the focus of this study, has been given attention mostly in the context of the recent migration crisis (especially in terms of asylum and illegal immigrants), while, consequently, the studies of the legal status and actual position of regular immigrants have been left out.

While the system of migration control and external border protection is mostly regulated at the EU level, voluntary and regular migrations are largely left to the national jurisdiction. The problem is that through the construction of impermeable and tighter mechanisms for controlling illegal migration, the legal ones are also being increasingly constrained. The states decide independently which categories of immigrants they find beneficial and most often issue temporary residence permits with limited economic and social rights according to the labour market needs. ${ }^{3}$ Thus, contemporary Croatian legislation approaches the matter of foreigners ${ }^{4}$ by adopting the basic principles and standards of EU legislation. ${ }^{5} \mathrm{~A}$

About the historical and socio-political context of migration in Croatia, see Bužinkić, E., et al., Pregled pravnog i institucionalnog okvira za zaštitu stranaca u Hrvatskoj, Centar za mirovne studije, Zagreb, 2013, pp. 57-58 [https://www.cms.hr/system/publication/pdf/39/Pregled_pravnog_i_institucionalnog_okvira_za_za_titu_stranaca_u_Hrvatskoj.pdf] Accessed 03.04.2019

2 According to migration statistics on the $1^{\text {st }}$ January 2018 published by Eurostat, the number of Croatian emigrants still outnumbers the number of immigrants. However, compared to other EU countries, a considerable proportion (12,9\%) of the resident population is foreign born, while 461200 , i.e., $11,2 \%$ of its total population are third country nationals. In 2017. Croatian citizenship was granted to 600 non-nationals outside the EU. Cf. Migration and migrant population statistics, [https:/lec.europa.eu/eurostat/statistics-explained/pdfscache/1275.pdf] Accessed 08.04.2019. Cf. also: Trend se mijenja, u Hrvatsku se doseljavaju stranci, Večernji list, 11.2.2019, [https:/www.vecernji.hr/premium/ trend-se-mijenja-u-hrvatsku-se-doseljavaju-stranci-1300104]. Accessed 09.04.2019; Za zapošljavanje stranaca u 2019. odobrena kvota od 65.100 dozvola, Točka na I - Medij za biznis, 21.12.2018, [https:// tockanai.hr/biznis/aktualno/zaposljavanje-stranaca-u-2019-19060/] Accessed 09.04.2019

3 Baričević, V., Azil i imigracije: perspektiva rubnih zona unije i prava migranata, Političke analize Vol. 2, No. 5, 2011, p. 31

4 Within this examination, the focus will be set only on the position of regular immigrants. Foreigners for the purpose of this study are therefore considered third country nationals, i.e., any person who is not a citizen of the EU within the context of Art. 20(1) of TFEU and who is not a person enjoying the EU right to free movement, as defined in Art. 2(5) of the Regulation (EU) 2016/399

5 The relevant documents are implemented primarily into the amendments of the Aliens Act (Official Gazette No 130/11, 74/13, 69/17, 46/18), which inter alia lay down the requirements for the entry, stay, and work of aliens in the Republic of Croatia as well as the Croatian Citizenship Act (Official 
very comprehensive legal framework covering various segments of the legal status of foreigners can hardly be considered restrictive. However, as is the case in many other fields of Croatian legislation, when it comes to its application on a practical level, the real deficiencies of the system responsible for its implementation emerge. In order to make migratory movements beneficial to the economic and social development of the country and society, the Migration Policy of the Republic of Croatia for the period 2013-2015 committed to ensuring the cooperation of all state offices and stakeholders in a timely and coordinated manner in order to effectively respond to potential problems of immigration. ${ }^{6}$ Nonetheless, recent statistics and studies on the legal status and foreigners' rights on Croatian territory point to the shortcomings in the practical application of these regulations, especially in the field of social, political, and cultural rights. ${ }^{7}$ Criticism is primarily directed against the perception of immigration as exclusively a security problem ${ }^{8}$ and a tool for political point-scoring 9 as well as non-transparent bureaucracy. ${ }^{10}$

Despite the fact that the issues of the legal status of foreigners have received particular attention only in recent decades due to the dynamics of social movements at the level of the European Union, it has not been ignored in Croatian legal historiography. Taking into consideration some features of the current migration legislation in the field of private and public law through the analysis of the relevant legal sources dating from the Roman times throughout its tradition in the late Middle Ages until the formation of modern Croatia in 1990, the main objective of this contribution is to question the continuity of the legal status of foreigners and ultimately offer some lessons for current immigration problems.

Gazette No 53/91, 70/91, 28/92, 113/93, 4/94, 130/11, 110/15) relevant for the acquisition of citizenship

6 Cf. Migration Policy of the Republic of Croatia for the period 2013-2015 (Official Gazette No 27/2013)

7 E.g., Bužinkić, et al., op. cit., note 1, pp. 50-57; Second European Union Minorities and Discrimination Survey, [https://www.cms.hr/system/article_document/doc/487/fra-2017-eu-midis-ii-main-results_ en.pdf] Accessed 08.04.2019

8 Migration is listed as one of the challenges within the framework of The National Security Strategy of the Republic of Croatia, which was adopted in 2017 (Official gazette No 73/2017). At the same time, an appropriate immigration policy in line with the needs of the labour market, the economic development of the country, and the increase of the integration potential of the society is considered one of its strategic objectives

9 Cf. Zbog predrasuda stranci u Hrvatskoj teško nađu posao, Nacional br. 1032, 18. 02. 2019, [https://www. nacional.hr/dossier-zbog-predrasuda-stranci-u-hrvatskoj-tesko-nadu-posao-2/] Accessed 09.04.2019

10 In terms of the most extensive challenges, Sajfert, who analysed the process of citizenship acquisition, pointed out the excessive duration of proceedings, noncompliance of the state officials with the prescribed administrative procedure, the margin of discretion that leads to discrimination against certain nationalities, the extensive paperwork, and the impossibility to appeal. Sajfert, J., Naturalisation Procedures for Immigrants - Croatia, Eudo citizenship observatory, 2013, pp. 2-7 


\section{THE ROMAN PERSPECTIVE - AN ANCIENT VIEW ON IMMIGRATION}

Viewed from today's perspective of a united Europe and globalization trends, the achievements of the Roman Empire in the creation of a common identity based on Roman citizenship that went beyond local particularities appears significant. Roman citizenship not only guaranteed a special legal status and personal identity to its holders but played a unifying element in the establishment of the empire, ${ }^{11}$ being able to "transform Gauls, Africans, Syrians into real human beings." ${ }^{12}$ Given that civitas primarily implied a privileged social and legal status, it should not be equated with the concept of citizenship in its contemporary meaning. Without closer examination of the specific features immanent to different statuses or gender within Roman society, in general, the citizenship provided various rights within public and private law. In the domain of ius publicum, the citizen was able to vote (ius suffragii) and participate in the political community holding magistrate offices (ius honorum). It also included the right and duty of military service and exemption from arbitrary physical punishment. Within ius privatum, citizenship enabled engagement in commercial transactions (ius commercium), allowed the conclusion of a lawful marriage (ius connubii), and provided the right to initiate and pursue legal process (legis actio) and to acquire property (ius Quiritium). The holder also possessed the legal capacity to make a will as well as to be instituted as heir via testament (testamenti factio activa \& passiva) along with powers and competences within the family (patria potestas, manus, tutela)..$^{13}$

11 In his celebration of Roman achievements, Aristides specifically highlights the citizenship as the way of sharing privileges as a unifying element and the essence for Roman hegemony. (Aelius Aristides, Roman oration 59-60: "But there is that which very decidedly deserves as much attention and admiration now as all the rest together. I mean your magnificent citizenship with its grand conception, because there is nothing like it in the records of all mankind. Dividing into two groups all those in your empire-and with this word I have indicated the entire civilized world-you have everywhere appointed to your citizenship, or even to kinship with you, the better part of the world's talent, courage, and leadership, while the rest you recognized as a league under your hegemony. Neither sea nor intervening continent are bars to citizenship, nor are Asia and Europe divided in their treatment here. In your empire all paths are open to all. No one worthy of rule or trust remains an alien, but a civil community of the World has been established as a Free Republic under one, the best, ruler and teacher of order; and all come together as into a common civic centre, in order to receive each man his due." Trans. cit. Oliver, J., H., The Ruling Power: A Study of the Roman Empire in the Second Century after Christ through the Roman Oration of Aelius Aristides, Transactions of the American Philosophical Society, Vol. 43, No. 4, 1953, p. 901)

12 Moatti, C., Translation, migration, and communication in the Roman Empire: three aspects of movement in history, Classical Antiquity, Vol. 25, No. 1, 2006, p. 117

13 Cf. amplius Sherwin-White, A., H., The Roman Citizenship, Part II, Ch. X, Oxford, Clarendon Press, 1939, pp. Taylor, T., S., Social Status, Legal Status and Legal Privilege, in: du Plessis, P., J. et al. (eds.), The Oxford Handbook of Roman Law and Society, 2016, p. 350 
As was typical for ancient legal systems, the Romans approached foreigners through principle of personality, according to which strangers (peregrines) did not share the jurisdictional privileges of Roman cives. Unless otherwise granted by a treaty, peregrines were free persons without any rights in the spheres of public or private law. Obtained either generally through an agreement between Romans and their national community or personally, they could have been given the right to conclude a legally valid marriage or contracts. Although excluded from civil litigation, they obtained protection through the institute of praetor peregrinus. The most difficult position by far was held by peregrini dediticii, foreigners who initially opposed the Roman rule and refused to join the union peacefully but were later conquered and subordinated to the authority.

Mobility being one of the core aspects of the state, it increased considerably due to pax Romana at end of the Republic and the beginning of the Principate. ${ }^{14}$ The whole Roman history is actually a tale of the gradual inclusion of foreigners in the circle of citizens, but this process has never been uniform. On the contrary, it reflected Roman economic and political interests and was based on granting privileges to those areas and foreigners that brought benefits. ${ }^{15}$ Just as in today's society, immigrants generated mixed feelings and divided opinions. On one hand, there were prejudices depending on their origin and nationality, ${ }^{16}$ while on the other hand, the reasons for their integration into Roman society were emphasized. ${ }^{17}$

14 The idea that borders are only constructions seems to exist already in the antiquity. A short oratio addressed by Pseudo-Aristides to an unknown emperor around the $3^{\text {rd }}$ century, praises the pax Romana and what seems like the freedom of movement. (Pseudo-Aristides, Eis Basilea 37: "Cannot everyone go with complete freedom where he wishes? Are not all harbours everywhere in use? Are not the mountains as secure for travellers as the cities for residents? Has not fear gone everywhere? What straits are closed? Now, all humanity seems to have found true felicity!")

15 On the example of communities in Roman Histria, Milotić showed the implementation of legal duality and the twofold distribution of Roman citizenship by granting the coastal region the whole scope of privileges while leaving the population of remote inland territories in the position of peregrini dediticii. Milotić, I., Legal Status of Peregrini and their Communities in Roman Histira, in: Thür, G; Lučić, Z. (eds.), Imperium und Provinzen (Zentrale und Regionen), Pravni fakultet Univerziteta u Sarajevu, 2006, pp. 99-110

16 E.g. Ulpian's opinion about the origin of slaves expressed in the first book On the Edict of the Curule Aediles D. 21,1,31,21: "Persons who sell slaves should always state their nationality, at the time of the sale, for very frequently the place of the nativity of a slave either attracts or deters the purchaser, and hence it is to our interest to know in what country he was born; for it is presumed that some slaves are good because they are sprung from a nation which has not an evil reputation, and others are considered to be bad because they are derived from a nation which is rather disreputable than otherwise. If the origin of the slave was not mentioned, an action on this ground will be granted to the purchaser and to all those interested in the matter, by means of which the purchaser can compel a slave to be taken back."

17 Such policy was advocated by a couple of Roman statesmen; Gracchus, Caesar, Claudius, Vespasian, and Hadrian being several of the most prominent ones. Tacitus reports the arguments of Emperor Claudius presented in front of the Roman senate as to why Gauls should get access to public offices. 
In order to manage the legal relations between citizens and foreigners as well as amongst foreigners themselves, Romans introduced a set of informal and flexible regulations ius gentium. ${ }^{18}$ This innovative and complex approach towards foreigners exercised its influence particularly in the field of commercial transactions by reinforcing mutual trust, the absence of which would hinder their relationship. The old legal system based on formal ius civile and accessible only to Roman citizens had to be abandoned and merged with the new one to achieve progress and enable the integration of foreigners. The process was aided by the jurisdiction of praetor peregrinus, a function introduced in 242 B.C.

Individual foreigners could have been granted the legal status of cives, or a less favorable ius Latii (privileges which included ius suffragii, ius commercii, ius connubii, and the acquisition of citizenship through immigration to Rome). Individuals were able to acquire citizenship most often through services to the Roman state, military service being a key manufactory for the production of Roman citizens. ${ }^{19}$ The citizenship could as well be granted to whole communities by assigning them a municipal status ${ }^{20}$ or

Recalling the mistakes of Athens by not integrating foreigners into their society, he advocates the naturalization of foreigners in order to achieve economic gain. (Tacitus, Annales 11,24: "In my own ancestors, the eldest of whom, Clausus, a Sabine by extraction, was made simultaneously a citizen and the head of a patrician house, I find encouragement to employ the same policy in my administration, by transferring hither all true excellence, let it be found where it will. For I am not unaware that the Julii came to us from Alba, the Coruncanii from Camerium, the Porcii from Tusculum; that - not to scrutinize antiquity - members were drafted into the senate from Etruria, from Lucania, from the whole of Italy; and that finally Italy itself was extended to the Alps, in order that not individuals merely but countries and nationalities should form one body under the name of Romans. The day of stable peace at home and victory abroad came when the districts beyond the Po were admitted to citizenship, and, availing ourselves of the fact that our legions were settled throughout the globe, we added to them the stoutest of the provincials, and succoured a weary empire. Is it regretted that the Balbi crossed over from Spain and families equally distinguished from Narbonese Gaul? Their descendants remain; nor do they yield to ourselves in love for this native land of theirs. What else proved fatal to Lacedaemon and Athens, in spite of their power in arms, but their policy of holding the conquered aloof as alien-born? But the sagacity of our own founder Romulus was such that several times he fought and naturalized a people in the course of the same day! Strangers have been kings over us: the conferment of magistracies on the sons of freedmen is not the novelty which it is commonly and mistakenly thought, but a frequent practice of the old commonwealth ... Now that customs, culture, and the ties of marriage have blended them with ourselves, let them bring among us their gold and their riches instead of retaining them beyond the pale!")

18 Gai. D. 1,1,9; Inst. 1,2,1

19 Cf. Sherwin-White, op. cit. note 13, pp. 311 sqq; Balsdon, J., P., V., D., Romans and aliens, Duckworth, London, 1979 pp. 82-96

20 As an example of Roman municipality on the territory of modern Croatia, see Karlović, T.; Milotić, I.; Petrak, M. Andautonia. An Example of Local Self-Government in Pannonia, Lex localis 13, 2015, pp. 35-48. The Roman model of administration gave local populations the possibility of self-government, ensuring peace in the provinces while at the same time introducing Roman governmental structures which facilitated the Romanisation and integration of local communities in the Roman state. Balsdon, ibid. pp. 84 
creating new colonies. ${ }^{21}$ Except Istria, which was a part of province Italia, the majority of modern Croatian territory was a part of Illyricum, later on split into Pannonia and Dalmatia. Since the native tribes opposed the Roman rule in $6 \mathrm{AD}$ in the Illyrian revolt, most of the inhabitants became peregrini. ${ }^{22}$ Although the same approach is surely not applied identically in all parts of the territory, the widely accepted standpoint, ${ }^{23}$ which Karlović elaborated on in the example of Andautonia, is that the Romanisation of provinces was conducted by granting the municipia ius Latii as an intermediary step for peregrine communities on their way to the acquisition of Roman citizenship through their services in local magistracies. ${ }^{24}$ Through gradual allocation of civic rights and inclusion of most loyal foreigners into the military or regional government service rather than by invasive policy, Roman authorities managed to stimulate foreigners to accept their values and Romanisation. ${ }^{25}$

The differences that were gradually erased mostly throughout commercial relations between citizens and foreigners in Roman populations over the course of time received their formal confirmation through emperor Caracalla's Constitutio Antoniniana issued in year 212, granting Roman citizenship to all free peregrini. ${ }^{26}$

Although pragmatic and interest-oriented while assigning legal capacity, we can conclude that the Roman approach to foreigners was indeed a unique and multicultural one. It tolerated the coexistence of cives with national and local peculiarities of peregrine communities, introducing a dynamic set of rules via ius gentium for the purpose of the efficient resolution of mutual disputes.

21 Since coloniae were established by Romans, compared to municipia, they had privileged status, and their inhabitants were considered cives. Cf. Soloman, E., Essai sur la condition juridique des étrangers dans les législations anciennes et le droit moderne, Paris, 1844, p. XLIII

22 For further studies on the development of Roman provinces, see: Mommsen, T. The Provinces of the Roman Empire from Caesar to Diocletian, vol. 1, Macmillan \& co., London, 1909, pp. 195-251; András M., Pannonia and Upper Moesia: A History of the Middle Danube Provinces of the Roman Empire, Routledge \& K. Paul, 1974

23 One of the main advocates for the concept of transitional status was Saumangne. Cf. Saumagne, C., Le droit latin et les cités romaines sous l'empire: essais critiques, Sirey, 1965, pp. 71sqq, 79sqq. The idea that peregrine communes were not admitted to Roman citizenship directly was backed up by Sherwin-White, who pointed out that from the time of Caesar onwards, Roman privileges were commonly granted to native communities in the form of Latin rights as a "bridge-status" rather than full franchise. After an intermediate period as a municipium Latini iuris, communities eventually secured the status of a full Roman municipium. Cf. Sherwin-White, op. cit. note 13, pp. 337-344

24 Karlović, T., The Legal Status of Municipium Andautonia, in: Thür, G; Lučić, Z. (eds.), Imperium und Provinzen (Zentrale und Regionen), Pravni fakultet Univerziteta u Sarajevu, 2006, pp. 59-61

$25 \quad$ Ibid. p. 68

26 The scope of this document is still being disputed today, but the generally accepted opinion is that it excluded peregrini dediticii. Cf. Sherwin-White, op. cit. note 13, p. 380 with instructions on further literature 


\section{THE POSITION OF FOREIGNERS IN THE MEDIEVAL STATUTES ON THE EXAMPLE OF DALMATIAN MUNICIPALITIES}

A very concrete approach to the question of the legal position of foreigners in the ancient Roman Empire encourages us to assume that medieval legal sources, due to the dynamics of social movements in the Middle Ages, were probably even more concerned with this legal issue. Through the analysis of the late medieval legal sources (12-14 $4^{\text {th }}$ century), this chapter is dedicated to the reconstruction of the legal framework of foreigners' protection. A special emphasis will be put on the status issues, the questions of civil litigation, and the protection of foreigners' political rights, to the extent possible within the observed period, as well as some economic issues which, when analysed, prove that according to mediaeval sources, the legal position of foreigners varied depending on whether the municipality gained some significant benefit from the settlements of foreign individuals or not.

Even at first glance, Croatian mediaeval law is characterized by the inequality of legal sources related to certain legal issues. ${ }^{27}$ Regarding the regulation of foreigners, some of its sources, mainly municipal town statutes, devoted more attention to it, while others referred to them only indirectly and casuistically depending on whether they were exposed to it in practice. Therefore, the analysis of individual issues related to the legal position of foreigners will be oriented exclusively to those statutory regulations which, in their content, foresee a special position for foreigners by respecting certain restrictions or, in some rare cases, by adding guarantees aimed at creating a favourable atmosphere for their settlement within the commune. Despite the fact that the medieval communes stimulated economic and cultural activity through their interaction or communication with foreigners, the normative role of the statutory provisions describing the position of foreigners was directed towards the achievement of the isolation of the city commune and thereby the protection of the position of the domestic population.

Describing the marginal position of foreigners in the social structure of Dalmatian communes during the Middle Ages, Raukar lists two categories of foreigners with

27 At the end of the $16^{\text {th }}$ century, the name of Croatia included the medieval Slavonia area, where significant influence of Hungarian law was observed when regulating certain private law relations. On the other hand, the areas of Istria and Dalmatia were marked by the relevance of the statutory law, which was primarily aligned with the interests of the Republic of Venice, while the Republic of Dubrovnik, thanks to its autonomous status over a period of several centuries, managed to establish a recognizable legal system known in legal history as a statutory right of the medieval Dubrovnik municipality. Beuc, I., Povijest država i prava na području SFRJ, Narodne Novine, Zagreb, 1989, p. 19 and 208; Kasap, J, Legal Regulation of the Borrowing Institute in Medieval Croatian Statutory Law, Pravni vjesnik Pravnog fakulteta u Osijeku, Vol. 32, No. 1, 2016, pp. 77-78 
whom the authorities of individual Dalmatian municipalities met within their work. The first group, to which attention will be given below, are the forenses that fit into the framework of the social and economic development of the commune and who, accordingly, had the opportunity to acquire the status of the commune citizens under certain conditions. The second group, which Raukar calls the viatores, consisted of travellers, pilgrims without the intention of permanent retention and thus the acquisition of civic status and related rights. ${ }^{28}$

\subsection{The concept of a foreigner and their ability to acquire citizenship status in medieval Dalmatian communes}

With very careful interpretation and comparison of certain urban legal codes, it can be concluded that the concept of a foreigner in the statutory provisions of Dalmatian cities is determined by several criteria that appear in the urban statutes with different frequencies. These are, first of all, the length of stay in the commune, the extent of obligations the foreigner contributed to the commune, and the ownership of real estate in the municipality that is taken into account as a purpose of the permanent retention of foreigners or their settlement in the commune. According to the ruling opinion in the domestic literature, a foreigner was considered anyone who was not related to the commune by birth and domicile. ${ }^{29}$

In the following, the analysis of some criteria will begin with the statutes of the southern Dalmatian city and island communes which, because of their geographic position or political and economic power, were often a refuge for strangers. Due to the systematic processing, the regulation of the topic from the title below will be divided into two legal circles, those of Dubrovnik and Split, the affiliation of which depends mostly on the geographical vicinity of the small island communes.

28 According to the definition contained in the statutory law, a forensis is any person born outside the city and its district which is not a subject to the municipal jurisdiction. See L, II, c. 80 The Statute of Šibenik, in: Grubišić, S., (ed.), Knjiga statuta, zakona i reformacija grada Šibenika, Muzej grada Šibenika, Šibenik, 1982 and L, V, c. 30. The Statute of Zadar in: Kolanović, J.; Križman, M. (eds.), Statuta Iadertina, Zadarski statut sa svojim reformacijama odnosno novim uredbama donesenima do godine 1563, Zadar 1997. The term forensis is most often used in the statutes of the Dalmatian communes to designate the term foreigner, while the term exstraneus was only exceptionally used to denote the same term. Cf. Birin, A., Pravni položaj stranaca u statutima dalmatinskih komuna, Zbornik - Odsjeka za povijesne znanosti Zavoda za povijesne i društvene znanosti Hrvatske akademije znanosti i umjetnosti (1330-7134) Vol. 20, 2002, p. 67; Raukar, T., Komunalna društva u Dalmaciji u XIV. Stoljeću, Historijski zbornik, Vol. 33-34, Zagreb, 1980-1981, p. 192; Raukar, T., Cives, habitatores, forenses u srednjovjekovnim dalmatinskim gradovima Historijski zbornik, Vol. 29-30, Zagreb, 1976-1977, pp. 139-149

29 See more in: Radić, Ž, Ratković, I., Položaj stranca u splitskom statutarnom pravu, Adrias: Zbornik radova Zavoda za znanstveni i umjetnički rad Hrvatske akademije znanosti i umjetnosti u Splitu No. 12, 2005, p. 196 and related literature in the note No. 26 
Thus, in the following section, we will be dealing with the statutes of the islands of Korčula, Lastovo, and Mljet as well as Ston, while in the wider area of the Split municipality, we are referring to the legal regulation present in the statutes of the islands of Hvar and Brač and the town of Trogir. ${ }^{30}$

Although the Statute of the City of Dubrovnik contains a wealth of information on the position of foreigners, the criteria defining the status of foreigners are left out, and it can be concluded that a multitude of individual provisions regulating the relations of Dubrovnik with the inhabitants of neighbouring municipalities define a foreigner simply as a non-citizen of Dubrovnik. ${ }^{31}$ The same is true of the definition of the position of a foreigner provided for in the provisions of the Korčula and Mljet Statutes. ${ }^{32}$ The aforementioned statutes did not foresee a special procedure for foreigners to obtain the status of full citizenship. On the other hand, the circumstance of ownership of real estate within the commune has been pointed out on the island of Korčula. ${ }^{33}$

The Statute of Split regulates the legal status of foreigners extensively. The statutory provisions refer to multiple aspects of their legal position, and the regulation of a special procedure of acquiring the right of full citizenship demonstrates the openness of the city towards social immigration. Terminologically, the statute refers to two categories of foreigners depending on the length of their stay in the city. Thus, the habitator signified the transitional level between the foreigner (forensis) and the citizen (civis). ${ }^{34}$ Citizenship was acquired by foreigners in a special procedure be-

30 About divisions in legal areas see more in: Kasap, op. cit. note 27, p. 77-78

31 See the provisions of the Statute Vol III, Ch: LI- LVII, in: Šoljić, A. et al. (eds.), Statut grada Dubrovnika, sastavljen 1272. godine, Državni arhiv u Dubrovniku, Dubrovnik, 2002. Numerous data based on insights into the archives of the City Council of Dubrovnik, related to the social and demographic structure of the foreign population, can be seen in a very detailed article: Janeković Römer, Z., Stranac u srednjovjekovnom Dubrovniku: izmedu prihvaćenosti i odbačenosti, Radovi Zavoda za hrvatsku povijest Filozofskoga fakulteta Sveučilišta u Zagrebu, Vol. 26 No. 1, 1993, pp. 27-38

32 The Korčula Statute refers to foreigners as to persons from other municipalities. Cf. Šeparović, Z. (ed.), Korčulanski statut, Statut grada i otoka Korčule iz 1214. godine, Književni krug, Split, 1987. Confirmation and annex to the statutory provisions of the city and the island of Korčula, Ch XLVI. On the same issue, the New Statute Booklet, Chapter LII, A foreigner is defined as "bomo extraneus de alia pruincia." Reformation of the Statute of Korčula Commune in Ch. CLXII extends the status of citizens of the commune to all foreigners living in the commune area and who are in the position of real estate there. The statute of Mljet does not define foreigners, but since the Statute of Korčula regulated legal relations for Mljet for some time, it can be concluded the situation on this issue was the same. Marinović, A., Veselić, I. (ed.), Mljetski statut, Statut otoka Mljeta iz 1345. Godine, 1. Izdanje, Književni krug, SplitDubrovnik, 2002

33 Šeparović, op. cit. note 32, The book of Reformations, Ch. 162

34 In that sense, according to the provisions of the Split Statute, the habitator had all the rights and duties as well as the citizen of the city, except being able to participate in political affairs. A foreigner acquired the status of a habitat after having lived in the city for more than six months. He had an obligation to 
fore the Grand Chamber, where they swore to obey the communal government's orders as well as their personal and property contribution to the commune with a special condition of permanent residence in the city. ${ }^{35}$ Unlike the Split Statute, the statute of Trogir omitted to regulate the standardization of the status of a citizen as well to include a special procedure for enabling this possibility for foreigners. ${ }^{36}$ The Statutes of the island of Brač and Hvar do not contain provisions that would specifically regulate the process of acquiring citizenship, although by extensive interpretation of a provision of the Brač Statute, it is possible to conclude that the adoption of the citizenship depended on both the approval of the governor and the decision of the council members. ${ }^{37}$ It is thus clear that the island communes, due to the limited resources and the basic needs of their population, tried to limit the settlement of foreigners. This is also supported by the fact that there was a general mistrust towards foreigners as expressed in the provisions of the statute. ${ }^{38}$

The statutes of the northern Dalmatian municipalities of Zadar and Šibenik were significantly more open to foreigners. Contrary to the aforementioned ones, these communes made it possible to obtain certain guarantees to facilitate the permanent settlement of foreigners in their area, encouraging their entire families, not just individuals. Thus, for example, the Zadar Statute exempts foreigners from paying municipal obligations on condition of permanent settlement in the city. ${ }^{39}$ Both statutes provide for a special procedure that allowed foreigners to acquire the

participate in free public works and givings as other citizens of the commune. See: Cvitanić, A.(ed.), Statut grada Splita, Statuta civitatis Spalati, II. Dotjerano izdanje, Književni krug, Split, 1987., New Statute, Chapter VIII

35 Cvitanić, op. cit. note 34, Vol. VI, Ch. I and II

36 The Statute of Dubrovnik is not the only statute that does not contain the definition of a foreigner. Although some of the provisions of the Statute regulate the legal position of foreigners in Trogir, foreigners were persons who were not citizens of the commune and were, in legal terms, discouraged. Berket, M.; Cvitanić, A.; Gligo, V. (eds.), Statut grada Trogira, Statuta et refomationes cicitatis Traguirii, Književni krug, Split, 1988., See: Word Interpreter, Forenses, extraneus, p. 830

37 Cvitanić, A. (ed.), Brački statut, Drugo prošireno dopunjeno i dotjerano izdanje, Književni krug, Split, 2006, II. The book of reformations, XV

38 Foreigners were perceived as people of evil intentions and the poor performance that came with the intent of destruction and theft of property. Cvitanić, op. cit, note 37, The book of reformations Vol III, Ch. IX

39 The foreigner was released from the obligation for a period of five years, except for the acquisition of real estate in the city where the period of release lasted for 10 years; Kolanović, J.; Križman, M. (eds.), Statuta Iadertina, Zadarski statut sa svojim reformacijama odnosno novim uredbama donesenima do godine 1563, Zadar 1997, Title IX, Book V, ch. 34 and 35; The provision refers to the economic development of Zadar in relation to other Dalmatian communes, e.g. Split; Raukar, T., Cives, habitatores, forenses u srednjovjekovnim dalmatinskim gradovima, Historijski zbornik, Vol. 29-30, Zagreb, 1976-1977, p. 143. The same is provided for in the provisions of the Pag Statute, in which the exemption from payment of "any sort of pressure" is for a period of 10 years. Čepulo, D. (ed.), Statut Paške općine, Statuta Communitatis Pagi, Pag, Zagreb, 2011, Vol I, Ch. 15 
status of citizens, which, apart from the vote of the majority, did not significantly differ from those mentioned in the provisions of the Split Statute. ${ }^{40}$

Ultimately, the analysis of the particular provisions of the Dalmatian statutes shows that all sources, to greater or lesser extent, regulated the problem of foreigners and their settlement in the municipality. While only a few of them foresaw guarantees to newcomers trying to provide them with a favourable climate for permanent residence, other communes, such as islands, due to the lack of resources and social and cultural isolation, sought to limit such a stay and permanent settling down. However, despite the content of the analysed statutory provisions, an attempt will be made to determine whether the mentioned limits were really carried out without exception or whether the communes provided exceptions of their restrictive policy in the case of beneficial economic interests.

\subsection{The legal position of foreigners in the statutory provisions}

The legal position of foreigners in the observed sources will be examined from different perspectives: primarily, in the public law domain in terms of the scope of political rights, if they can be recognized in the provisions of certain sources, as well as in the domain of private law with regard to the aspect of property and the procedural position in civil and criminal lawsuits. Before individual analysis of these issues, it is important to note that the fundamental regulator of the legal position of foreigners in Dalmatian communes is the principle of reciprocity. ${ }^{41}$ Even before the statutory norms, the towns tried to resolve the relations with foreigners through this principle, which is evident in the bilateral agreements quoted by Birin. ${ }^{42}$ The Dubrovnik Statute provides, therefore, for a special regulation of relations between Dubrovnik and the inhabitants of neighbouring municipalities according to the customs of the third book of the Statute. ${ }^{43}$ The application of

40 While in Split and Zadar, it was necessary to have a decision of the regular majority for citizenship; a two-thirds majority of council members was required in Šibenik. Kolanović et al., op. cit, note 39, The Statute of Zadar V, 35; Grubišić, $o p$. cit. note 28, The Statute of Šibenik II, 80 and 81

${ }_{41}$ Šeparović, op. cit., note 32, Ch 14 of the old edition and Ch 62 of the new edition of the Statute of Korčula. The principle of reciprocity is also referred to by the Statute of Split in fiscal matters (see: Cvitanić, op. cit. note 34, Cvitanić, op. cit., note 34, The Statute of Split, III, 49-57, VI, 8; the book of reformations, 76), Cvitanić, op. cit,. note 37, The Statute of Brač, II, IX and the Statute of Hvar II, XXXXV, Berket et. al, op. cit. note 36, Berket, et. al, op. cit. note 36, The Statute of Trogir I, 21, Grubišić, op. cit. note 28, The Statute of Šibenik II, 8, Kolanović, et. al., op. cit., note 39, The Statute of Zadar, II, 8

42 The author cites a contract between Dubrovnik and Molfetta from 1148; between Pisa, Dubrovnik, and Split from 1169, and between Ancona and Trogir from 1236. Birin, op. cit., note 28, p. 68

43 The third book in chapters LI-LIII Regulates the relations of Dubrovnik with the inhabitants of the Hum Principality, Bosna, Raška, and Zeta, as well as the inhabitants of the towns of Upper Dalmatia and the other Slavs. 
the principle of reciprocity in places where individual regulation is missing was the only possible criterion for regulating mutual relations in cases where common higher hierarchical power was non-existent. ${ }^{44}$

There are few statutory provisions referring to the position of foreigners in terms of their political rights. To a greater extent, political rights can only be determined by the interpretation of provisions on the conditions for the choice of holders of certain administrative functions in the Dalmatian communes. According to the research conducted in the legal literature almost without exception, the possibility of participation in municipal services was related to the citizenship of the municipality. ${ }^{45}$ Some exceptions were foreseen but only for cases involving city officials most often engaged in activities required by the communes, such as physicians, and there were no citizens who, due to the lack of the competence of the service concerned, could accept it. ${ }^{46}$

All the aforementioned about the status of foreigners in the Dalmatian communes becomes more apparent if we look at the foreigners' ownership rights. A large number of provisions that have been standardized by the legal interaction of foreigners and citizens of the municipality included a limitation of the irrelevant relations between the citizens of the municipality. They are limited and exhaustive and cannot be fully presented in the context of this research, but some of them clearly point to the role of foreigners in the economic development of the medieval city and are therefore mentioned below. In particular, we are going to refer to the possibility of acquiring real estate or valuable movables with a special note that the above-mentioned issues were the objects of scientific research numerous times. Thus, we are going to try to present the most important conclusions drawn from a very rich analysis. Under this criterion, legal sources can be categorized into exceptional ones, those which expressis verbis did not foresee restrictions on

44 Cvitanić, A., Iz dalmatinske pravne povijesti, Književni krug, Split, 2002, p. 648

45 Grubišić, $o p$. cit., note 28, The Statute of Šibenik II, 82; Cvitanić, op. cit., note 34, The book of reformations II, vol. 21, ch 11

${ }^{\mathrm{M}}$ ost sources do not explicitly regulate the issue of participation in the performance of utility services, but the provisions on the manner in which city councillors or civil servants were chosen do not leave room for doubt. See for example: Čepulo, op. cit., note 39, The Statute of the Municipality of Pag, I, 23, The Statute of Lastovo, Chapter 49. Special attention is required to regulate the statutes of certain municipalities that were under Venetian supremacy during the observed period. These municipalities foresaw the possibility that most communal functions are performed by Venetian representatives. But, they were not considered foreigners in terms of forenses. See: The Statute of Rab Municipality, V, II. Margetić, L.; Strčić, P., Statut rapske komune iz 14. stoljeća = [Statut communis Arbae], Adamić, Rab, Grad Rab; Rijeka, 2004. The Statute of Hvar, I, 27. Cvitanić, A., (ed.), Hvarski statut, Statuta Communitatis Lesinae, Književni krug Split, 1991

46 See more in: Birin, op. cit., note 28, pp. 83-84 
the ability to acquire assets to foreigners and those which explicitly prohibited or restricted such possibility, i.e., in extremely unfavourable conditions.

The Dubrovnik Statute does not refer to this issue, and it could be concluded that there were no restrictions on the acquisition of real estate. This is also supported by a very clear provision of the statute that entitles all foreigners whose property was sold or disposed of during their stay outside the city to file a complaint within two years of the conclusion of a legal transaction so as to return the property to its possession. ${ }^{47}$ The statutes of islands that were under the jurisdiction of the Dubrovnik legal circuit referred to this issue differently. As the Lastovo Statute maintains the views of the Dubrovnik commune in terms of legal regulation since it was under its authority for a certain period of time, in order to comprehend these issues, we are going to refer to Provision 37 of the Statute, which explicitly forbids the acquisition of property to all but the citizens of the island. ${ }^{48}$ The Korčula Statute, on the other hand, allows foreigners the possibility to acquire real estate. ${ }^{49}$ However, according to the ruling opinion in the reference legal literature, this provision was subsequently amended, and foreigners were prohibited from owning the existing (with the right to sell) and acquiring new real estate on the island. ${ }^{50}$

The statutes that we have previously classified under the Split legal circle refer to this matter differently. The Split Statute does not forbid the acquisition of real estate, but in terms of foreigners, this possibility is significantly restricted by the compulsory approval of the Grand Council. ${ }^{51}$ The Statutes of the islands of Brač and Hvar stipulate restrictions on the sale of island real estate to foreigners by the Grand Chamber's consent but also by the islanders' right of pre-emption. ${ }^{52}$ Radić pointed out that the Trogir Statute recognized the ban on acquiring real estate by foreigners but only in its later edition. ${ }^{53}$ It seems that the ban did not exist before,

47 Šoljić, et al., op. cit., note 31, Book 8, LXXII

48 The Statute of Lastovo, ch 37. Later, in the year 1486, the Dubrovnik Chamber supplemented this provision by defining null and void all legal affairs that had permanently and temporarily alienated real estate. See ch. 87 of the statute. Lastovski statut, (ed. Cvitanić, A.), Književni krug, Split, 1994. The same provision is also contained in the Mljet Statute, ch. 30. Marinović; Veselić, op. cit., note 32

49 Šeparović, op. cit., note 32, The book of reformations, ch CXCIV. Attention is drawn to the part of the provision which obliges all foreigners who own the real estate on the island to contribute to all communal charges

50 Šeparović, op. cit. note 32, The book of reformations, ch CII. For more details: Radić; Ratković,, op. cit, note 29, p. 216 with attention to the note 146

51 Cvitanić, op. cit., note 34, The Statute of Split, I, 21

52 Cvitanić, op. cit., note 37, The Statute of Brač, The book of reformations Vol. I, 79

53 Radić; Ratković, op. cit., note 29, p. 215 
and the later adopted provisions of the statute testify that it was often neglected in practice. ${ }^{54}$

The statutes of the northern municipalities explicitly ban the possibility of acquiring real estate to foreigners, even when the legal basis for the acquisition is based on inheritance or legacy. ${ }^{55}$ The statute of Pag excludes the possibility of acquiring real estate property to foreigners irrespective of the acquisition basis. ${ }^{56}$ This provision did not seem to apply to foreigners whose intention was to permanently settle on the island. It is similarly stated in the provision of the Zadar statute. ${ }^{57}$ The preemption right of the citizens of Pag in the case of sale of real estate, but also the possibility of redeeming a property already sold to foreigners, is another provision that discriminates against foreigners in terms of real estate acquisition and limits the possibility of property gains in their favour. ${ }^{58}$

The position of foreigners in medieval law in virtually all of the quoted sources reflects the actual relationship of the commune to that category of individuals. It is difficult to find a common link in a number of sources as all refer to cases that have marked the jurisprudence of individual municipalities, but it can be argued that deviations from the ordinary court procedure in most cases did not favour the interests of foreigners.

Rules on the implementation of an urgent procedure in the case of legal disputes of foreigners, which are most clearly defined in the Split Statute, are outlined since, in addition to Dubrovnik, Split was the most important trade centre for exchange with other communes. But, we have to see how a special, i.e., urgent procedure without procedural formalities, as well as litigation on otherwise-nonworking days, marks the special position of foreigners in almost all of the Dalmatian communes whose earlier statutes have been referred to.

The oath of the governor's deputy in the provisions of the Dubrovnik Statute also includes the obligation to hold litigation on Sunday in disputes of foreigners and islanders and peasants who lived outside the city and were under the jurisdiction of Dubrovnik. ${ }^{59}$ As the island of Korčula belongs to the same legal circle, it is not surprising that the shortening of the procedure was foreseen in the provisions of the

\footnotetext{
54 Berket, et. al, op. cit., note 36, The Statute of Trogir, IV, 45, The book of reformations Vol. I, 17 (1369); I, 62 (1390)

55 Grubišić, $o p$. cit., note 28, The Statute of Šibenik, IV, 45

56 Cepulo, op. cit., note 39, The Statute of the Municipality of Pag, IV, 31

57 Kolanović, et al, op. cit., note 39, The Statute of Zadar, III, 17, and V, 34

58 Čepulo, op. cit., note 39, The Statute of the Municipality of Pag, III, 42

59 Šoljić, et al, op. cit., note 31, 8, I
} 
Korčula Statute.$^{60}$ In medieval Split, litigation of foreigners was enabled in an urgent procedure, and on those days in which it was not allowed for the citizens of Split, i.e., "on holiday and non-holiday days [...] without any delay and procrastination". ${ }^{61}$ It is similarly provided for in the content of the Zadar Statute, although the provision is more specific concerning the nature of the procedure. An urgent procedure is foreseen only in cases of dispute between foreigners and citizens of Zadar and foreigners if a dispute arises during travel in regard to movable property while respecting the provisions of the statute of such disputes. ${ }^{62}$ In the context of the protection of property rights of foreigners, there is a noticeable provision of the Trogir Statute, which obliged citizens on the payment of claims, i.e., goods to foreigners without delay and payment of fines to the municipality if the deferral occurred. ${ }^{63} \mathrm{~A}$ provision of similar content cannot be established in the content of other sources.

Undoubtedly, the above-mentioned provisions, apart from encouraging foreign trade, sought to enable their urgent departure from the city. Therefore, when it comes to their real purpose, it can be concluded that the same principle privileged the position of foreigners, but they were indeed protecting the economic interests of the municipality.

Even more decisively, the communes secured their public order against the negative influences of foreigners by criminal law provisions that deviated from the institutes or procedures prescribed to the citizens. There are a number of cases in which the position of the foreign population was evidently unfavourable, which is particularly highlighted in the following cases. Thus, communes have given their citizens special self-help rights when dealing with foreigners who committed any kind of offense, personal or property, or have entered the commune with criminal intent. ${ }^{64}$ For citizens who acted in the aforementioned manner, there were fore-

${ }^{60}$ In the event of a dispute with foreigners, the islanders were obliged to respond immediately or as soon as possible at least two days after filing a lawsuit if the foreigner stayed for a long time on the island. Šeparović, op. cit. note 32 , ch. 32 of the old edition, and ch. 35 of the new editions. It is obvious that a shortened procedure was possible in commercial but also in other obligatory business. See more about the peculiarities of the shortened procedure in some Dalmatian communes in: Radić; Ratković, op. cit., note 29 , p. 211 , note 126

61 Birin, op. cit., note 28, p. 69; Cvitanić, op. cit., note 34, I, 5 and III, 5

62 Kolanović, et al., op. cit., note 39, The Statute of Zadar, Reformations, 78

63 Berket, et al., op. cit., note 36, The Statute of Trogir, II, 48. Birin states that similar regulation is also represented other statutes, although in some cases it is standardized as a down payment, i.e. bail indicating validity of a concluded legal business. Kolanović, et al., op. cit., note 39, The Statute of Zadar, III, 25-26; Cvitanić, op. cit. note 34, III, 96; Šoljić, et al., op. cit., note 31, 8,17; Šeparović, op. cit., note 32 , ch 38 of the old edition, ch. 35 of the new edition, Birin, op. cit., note 28, pp. 70-71

64 This issue is referred to in details in The provisions of the Split Statute, IV, 32 (Cvitanić, op. cit., note 34) and of the Reformations, ch. 99 and the provisions of the Trogir Statute, II, 10 (Berket, et al., op. cit., note 36) The provisions differ depending on the modalities of the offense and the way of proving 
seen the exclusions of unlawfulness for the consequences caused. Furthermore, the possibility of deviating from the usual method of punishment for foreigners and arbitrariness when measuring the amount of compensation in case of injuries is another factor contributing to the claim on the marginalized position of foreigners in the Dalmatian communes. ${ }^{65}$ The most southern communes were most reactive to foreigners, while the statutory deviations in the statutes of northern municipalities in the case of offenses caused by foreigners were conditioned by special evidentiary procedure ${ }^{66}$ However, the cause of differences in the provision of certain sources must also be sought in the period from which the statutes of the northern municipalities are given. Obviously, with the passing of time, the negative attitudes toward foreigners were mitigated by the interests the municipality had regarding their stay in the city. It was no wonder, therefore, that there was a greater tolerance when determining their legal position.

\section{LEGAL STATUS OF FOREIGNERS IN CROATIA AND SLAVONIA FROM THE MIDDLE AGES TO 1848}

In the feudal period in the Kingdom of Croatia and Slavonia, there was a distinction between the domestic people (state members) and foreigners, and so was the case in the rest of the Hungarian-Croatian Kingdom. ${ }^{67}$ Thus, Venetians, French and Austrians were considered foreigners, as were Hungarians regarding the use of autonomous Croatian-Slavic rights. Namely, this distinction was due to the special position of the Kingdom of Croatia and Slavonia within the countries of the Hungarian Crown and the Croatian-Hungarian Kingdom. ${ }^{68}$

the injury, but in both cases the intent is the same. The Statutes of the Northern Communes also refer to this issue. For more information see: Kolanović, et. al., op. cit., note 39, Zadar Statute, V, ch. 11, and Grubišić, op. cit. note 28, Šibenik Statute VI, 96. A very detailed explanation of certain provisions can be seen in: Radić; Ratković, op. cit., note 29, pp. 221-222

65 About arbitrariness when setting the sentence see in more details the Provisions of Split Statute (Cvitanić, op. cit., note 34, IV, 43) and Trogir Statute (Berket, et. al., op. cit. note 36, II, 7, II, 49)

66 Šoljić, et al., op. cit., note 31, IV, 33 which implies the nose cut of the maid who received a foreigner in the house. Or the provision of the Lastovo Statute in ch. 110 which limited the residence of foreigners to the island area for a maximum period of 10 days. Radić; Ratković, op. cit. note 29, p. 222. When it comes to the statutes of the northern municipalities, The Statute of Rab for the commission of crimes (theft) against foreigners foresees an equally rigorous procedure as in other cases and the application of the principle of reciprocity which is excluded in criminal proceedings against foreigners in the southernmost communes. The Statute of Rab, IV, 44 and 47 The Pag Statute do not even contain provisions on the different punishment of aliens. Margetić, et al., op. cit., note 45, The Statute of Rab, IV, 44 and 47. The Staute of Pag does not contain provisions on the different punishment of foreigners

${ }_{67}$ Kosnica, I., Državljanstvo i Opći građanski zakonik u Kraljevini Hrvatskoj i Slavoniji od 1853. do 1879., Zbornik Pravnog fakulteta u Zagrebu, Vol. 63, No. 5-6, 2013, p. 1145

68 Kosnica, I., Gubitak državljanstva u Hrvatskoj i Slavoniji od Bachovog apsolutizma do raspada Monarhije, Pravni vjesnik, Vol. 29, No. 3-4, 2013, p. 62 
In the Croatian-Hungarian Kingdom, the citizenship was one and unique, and so all the members of the Kingdom of Hungary and of the Kingdom of Croatia and Slavonia were considered citizens of one such state (indigenae). On the other hand, foreigners (alienigenae, peregrini) ${ }^{69}$ stood in front of the HungarianCroat nationals. Therefore, foreigners were all those who were not citizens of the Hungarian-Croatian Kingdom but who were newcomers (advenae) in this area for a long time or were only passing through (transeuntes). If they resided abroad and had possessions in the area of the Hungarian-Croatian Kingdom or came to perform certain business activities, then they were called (forenses). ${ }^{70}$

The Hungarian-Croatian laws at that time did not recognize foreigners as citizens of the Kingdom despite having illegally owned real estate in the area, performed public services, enjoyed church privileges (donations), or dealt with crafts and trades. Hence, even a longer period of regular stay in the territory of the Kingdom of Hungary could not replace the acquisition of citizenship. ${ }^{71}$ Accordingly, all citizens of the Kingdom of Hungary who stayed in this area were considered to be citizens in the broad sense of the word. Thus, Greeks, Armenians, and Serbs were granted the right to trade freely since they were considered to be permanent citizens (incolae), i.e., citizens and not advenae.

Considering all the above, it can be stated that, under the law, foreigners could not obtain the noble title of the Kingdom of Hungary, perform public services, or have the right to act on state affairs; furthermore, they could not receive church donations (jobs), own real estate, or freely deal with crafts or trades. The aforementioned rights were only the rights or privileges of the citizens. ${ }^{72}$

In spite of the above-mentioned prohibitions regarding the acquisition of certain national privileges, there were certain exceptions. Namely, the foreigners had the right to perform mining and military service even though the advantage was given to citizens in this matter. Similarly, in terms of trade, the principle of reciprocity was, in relation to other countries, respecting the concluded international treaties and allowing foreigners to participate in public fairs. ${ }^{73}$

69 Lanović, M., Privatno pravo Tripartita za nastavne potrebe Pravničkog fakulteta, Tipografija d.d., Zagreb, 1929, p. 141

$70 \quad$ Ibid.p. 142

$71 \quad$ Ibid. p. 144

72 Ibid. More on acquisition of citizenship by dividing citizens and citizens' rights see in: Dabinović, A., Statutarno pravo grada Zagreba, Mjesečnik: glasilo hrvatskoga pravničkoga družtva, No. 1-2, Zagreb, 1943, pp. $1-14$

73 Lanović, op. cit. note 69, p. 144 
However, regarding the acquisition of real estate by foreigners, the legal provisions were much stricter. Thus, every citizen could simply buy an estate from a foreigner, while in respect of the realization of the pledged right, it was sufficient for him to lay down the amount paid without taking into consideration any other deals among negotiating parties. In addition, citizens also had the pre-emption right concerning the city real estate. Consequently, in order for foreigners to be completely excluded from property rights, it was stipulated that foreigners could not buy the debts (bonds) of Hungarian-Croatian citizens. ${ }^{74}$

\section{LEGAL STATUS OF FOREIGNERS IN CROATIA AND SLAVONIA FROM 1848 TO 1918}

At the end of the 18th century, after the American and French Revolutions, a radical change in the position of foreigners came about on the basis of the idea of the equality of all people, improving the legal status of the citizens in the countries where they did not have citizenship. ${ }^{75}$ The revolution in 1848 created the preconditions for introducing modern citizenship. Thus, with the introduction of the Octroyed Constitution of March 4, 1849, an Austrian citizenship for the entire monarchy was established in Croatia and Slavonia. ${ }^{76}$ However, as this Constitution was not of a long term and there was a certain legal void, the authorities decided to extend the Austrian General Civil Code (hereinafter GCC), which entered into force on 1 May $1853^{77}$ to the countries of the Hungarian Crown, which also included Croatia and Slavonia. The GCC should have been equally applied to all citizens as a 'general' rule, and full enjoyment of civil rights was allowed only to nationals. ${ }^{78}$ However, this provision was limited by the content of the provision in Art. 33 of the GCC, according to which foreigners were in an equal positions with citizens regarding civil rights and obligations, in a parental position with nationals but conditioned by reciprocity. Consequently, it was stipulated that if the state of a foreigner would restrict the rights of foreigners vis-à-vis their own nationals, then the same would apply in these areas. For example, Turkish citizens were not able to acquire property on the real estate in this area because the foreigners were excluded from that right in Turkey. Accordingly, a foreigner could acquire real

\footnotetext{
$74 \quad$ Ibid. p. 145

75 Krbek, I., Pravo javne uprave FNRJ (Osnovna pitanja i prava gradana), Birozavod, Zagreb, 1960, p. 237

76 Kosnica, I., Utvrdivanje državljanstva u Hrvatskoj i Slavoniji 1849.-1880., Zbornik radova Pravnog fakulteta u Splitu, Vol. 51, No. 3, 2014, p. 699

77 Vuković M., Opći gradanski zakoniks novelama i ostalim naknadnim propisima, Školska knjiga, Zagreb, 1955, p. V

78 See article 28 of the General Civil Code. Derenčin, M., Tumač k obćemu austrijskomu gradjanskomu zakoniku, knjiga I., Nakladom Sveučilišne knjižare Albrechta i Fiedlera, Zagreb, 1880, p. 190
} 
estate property in this area, be entitled to inheritance, sue a citizen or a foreigner at a 'domestic' court, enjoy the same rights as citizens in bankruptcy proceedings, and freely deal with crafts and trade. ${ }^{79}$

Legal and business abilities of foreigners were generally judged on the basis of the law of the country a foreigner belonged to or was a citizen of, taking into account two criteria — residence and birth. ${ }^{80}$ There were also exceptions of the above-mentioned rules in the following cases: the provisions of the GCC relating to the prohibition of slavery, polygamy, the so-called institution of civil deaths, limitations of legal capacity with regard to religion, etc. Thus, in these cases that we have not mentioned as exceptions, the legal and business capacity of foreigners was judged according to the laws of the state they were a member of. ${ }^{81}$

Concerning the conclusion of the contract, the GCC provides two situations depending on whether a foreigner made a contract in this country or abroad (either with a foreigner or a citizen). Thus, in the first case, Art. 35 of the GCC stipulates that if a foreigner signs a contract in this country, and binds himself to the agreement, the validity of the contract will be judged either under this law or the law of the country he is a citizen of. Hence, it all depends on which of these laws this agreement is valid upon. ${ }^{82}$ On the other hand, if a foreigner entered into a doublesided binding agreement with a national in this country, the provisions of this code would apply with regard to the interpretation of the rights and obligations of the parties. Likewise, the provisions of this code would apply even if a foreigner enters into a double-sided contract with another party in this country unless the parties, at the conclusion of the contract, expressed the will to apply another law (the parties could choose between the laws of the place where they settled the contract and the place where the contract must be completed).$^{83}$ In the second case, that is, if a foreigner concluded an agreement abroad, irrespective of whether the agreement was concluded with another foreigner or a national citizen, the provisions of the law of the place where the contract was concluded would be applied unless the parties agreed to apply the law of another place. ${ }^{84}$

Apart from the GCC, the legal position of foreigners was regulated by the Law on the Establishment of Municipalities in the Kingdom of Croatia and Slavonia of 1881 and 1895 , which stipulated that foreigners were entitled to demand that the

See Art. 33 of the GCC. Ibid. p. 207

See Art. 34 of the GCC. Ibid. p. 210

Ibid. pp. 212-214

Art. 35 GCC. Ibid. pp. 214-215

Art. 36 GCC. Ibid. p. 215

Art. 37 of the GCC. Ibid. p. 217 
city area protect them and their property that was located in the city area and to allow them to use city bureaus. They were also obliged to bear municipal expenses fairly. ${ }^{85}$

\section{LEGAL POSITION OF FOREIGNERS FROM 1918 TO 1990}

After the founding of the Kingdom of Serbs, Croats and Slovenes (hereafter KSCS) in 1918, the issue of regulating the legal status of foreigners was mainly based on numerous laws and regulations, many of which came from the middle of the $19^{\text {th }}$ century, and the peace treaties and intergovernmental treaties concluded by the Kingdom with neighbouring countries. Namely, at the beginning of existence, the Kingdom of Serbs, Croats and Slovenes represented a legal mosaic composed of six different legal areas: the Croatian-Slavonian, the Slovene-Dalmatian, the former Hungarian territory (Prekmurje, Međimurje, Baranya, Bačka and Banat), the Bosnian-Herzegovinian, and the Serbian and Montenegrin. ${ }^{86}$ Thus, each legal area partially retained own rules regarding foreigners. For example, in the area of the former Kingdom of Serbia, the provisions of the Civil Code of the Kingdom of Serbia (hereinafter CCKS) were very important. The CCKS stipulates that in respect of personal rights and freedoms of such property, foreigners enjoy equal legal protection as Serbian citizens. ${ }^{87}$ Accordingly, it was determined that the parties enjoy personal rights and rights over property except when the enjoyment of these rights was not related to seeking Serbian citizenship. ${ }^{88}$ In general, the rule of factual reciprocity was applied since, in all cases where a foreign state treated Serbs as their own nationals, the laws that were applicable in this area would also apply in the same way to foreigners as well as their own citizens. In case of doubt,

85 According to the Basics of the Law on the Organization of Free and Royal Cities and Legitimate Trades in Croatia and Slavonia since 1861, in addition to equal obligations as citizens, the only rights foreigners had were the right to personal security and the protection of property and the right to use city institutes. The legal status of foreigners was also envisaged by the Government's Draft Law on the Establishment of Town Halls in the Kingdom of Croatia and Slavonia of 1879, according to which the foreigners had all the same obligations as the citizens of the municipality but without having the same rights except for that of unhindered residence but under the condition of unprovoked rule and possession of the means of nutrition and the condition of legitimizing with the citizenship permit. The Government's basis of the Law on the Establishment of Town Halls in the Kingdom of Croatia and Slavonia, according to: Čepulo, D., Položaj i ustroj hrvatskih gradova prema Zakonu o uređenju gradskih općina iz 1881. godine, Hrvatska javna uprava: časopis za teoriju i praksu javne uprave, Vol. 2, No. 1, 2000, p. 98

86 Pavlović, M., Problem izjednačenja zakona u Kraljevini Srba, Hrvata i Slovenaca / Jugoslaviji, Zbornik Pravnog fakulteta u Zagrebu, Vol. 68, No. 3-4, 2018, p. 494

87 Art. 15 CCKS (1844). Ristić, A., M., Pravni položaj stranaca, doctoral thesis, Beogradski univerzitet Pravni fakultet, Beograd, 1934, p. 77

88 Art. 45 CCKS (1844). Ibid. 
a foreigner had to prove it. ${ }^{89}$ The enjoyment of "civil rights", as set forth in Art. 44 of CCKS, could refer not only to the rights covered by this law but also to the political rights, and in that case, this provision should be in the Constitution and not in this law. ${ }^{90}$

Despite the fact that foreigners were equal with domestic citizens in respect of the enjoyment of certain private rights, there were certain restrictions. Namely, upon the establishment of the Kingdom of the Serbs, Croats, and Slovenes (hereinafter SCS), a new provision was introduced regarding the acquisition of real property rights by a natural person. Thus, foreigners were made difficult to acquire immovable property in an area near the state border and the coastline at a distance of 50 $\mathrm{km}$ from the border. ${ }^{91}$ In addition to reciprocity, regarding the acquisition of real estate in the area, it was necessary to obtain the approval of the army, navy and interior minister. ${ }^{22}$

However, there is a group of rights enjoyed exclusively by citizens of a certain state, and those are political rights. Namely, there was an established rule, which exists even today, that foreigners did not have active and passive voting rights, that is, that they had no choice of legislature or bodies of local government units. Nevertheless, two states represented an exception, namely, the Soviet Union and the Kingdom of SCS/Yugoslavia..$^{93}$ According to the Act on the Election of People's Representatives to the Constitutional Assembly of 3 September 1920, the voting right was also given to the Slavs who had permanent residence anywhere in the Kingdom of the SCS (so the number of fugitives from the Russian Empire was also given a voting right). ${ }^{94}$ Accordingly, foreigners were neither allowed to be members of political organizations nor to form associations. ${ }^{95}$

89 Art. 47 CCKS (1844). This principle was also applied to inheriting foreigners in this area. Ibid.

90 Article 44 CCKS (1844): "A Serbian citizen is entitled to the full enjoyment of civil rights. Citizenship of Serbia is earned either by birth or inheritance; which means that all Serbian citizens are either born or naturalized Serbs and they all enjoy civil rights. In case of born Serbs, citizenship is passed from parents to their children by nature. In the case of naturalized Serbs, citizenship is earned if a foreigner spent seven years in the state service, craftsmanship or agriculture, or in any other secondary occupation providing that all that time he lived in accordance with the laws, without doing any crime. Should a foreigner spend less than seven years of residing in the country in question, a citizenship was granted only by the special permit of the Governor with the consensus of the Council." Ibid. p. 79

$91 \quad$ Ibid. p. 89

92 Art. 48 of the Law on the budget's twelfth for July, August and September 1923. Ibid.

93 Ristić, op. cit. note 86, p 80

94 Ibid.; Balkovec, B., Izborno zakonodavstvo prve jugoslavenske države (1918. - 1941.), Časopis za suvremenu povijest, Vol. 48, No. 1, 2016, p. 200

95 Art. 1, 17, 21 and 24 of the Law on associations, gatherings and arrangements, Official Gazette of the Kingdom of Yugoslavia No. 225/1931 
The second group of political rights which foreigners were excluded of represented the whole sequence of public functions of political character, the first of which was the state service. Thus, the basic rule was that a foreigner was not allowed to perform the function of a state clerk; he was not allowed to be a judge or to hold any function in judicial affairs. ${ }^{96}$ Also, foreigners were not allowed to be lawyers or public notaries. ${ }^{97}$

The first Constitution of the Federal People's Republic of Yugoslavia (hereinafter FPRY) was passed in January 1946 and after the Communist conquest of power 1945. ${ }^{98}$ This Constitution in Chapter V introduces articles defining "the rights and duties of citizens", but the same apply only to nationals. Namely, the abovementioned articles on citizens usually refer to citizens while expressly referring to foreign nationals only in Art. 31 (right of asylum). ${ }^{99}$ Thus, via this provision, it was established that foreign nationals were persecuted for the purposes of promoting democratic principles, national liberation, the rights of the working people, and the freedom of scientific and cultural work. ${ }^{100}$ Despite this and the fact that it could be concluded from some of the provisions of the Constitution (for example, in Art. 28, para. 2 and 5, the term 'citizen' is replaced with 'nobody') that they also apply to foreigners, they, as a rule, could not invoke the constitutional provisions. ${ }^{101}$ This did not mean that the parties were completely disenfranchised but that their public and private law positions were regulated and protected by special laws. Thus, under the Constitution of the FPRY, foreigners were entitled to those rights that were similar to the basic rights of citizens ${ }^{102}$ but they were not their constitutional rights. Consequently, the principle of the equality of citizens did not apply to foreigners; that is to say that they were to be treated equally with citizens.

Restrictions on the rights of foreigners who then existed and influenced their legal status were needed because of the political circumstances at that time. Thus,

96 Art. 2 of the Law on Judges of Regular Courts of the Kingdom of Serbs, Croats and Slovenes, Official Gazette of the Kingdom of Serbs, Croats and Slovenes No. 295/1928

${ }_{97}$ Art. 2 of the Law on Lawyers of the Kingdom of Serbs, Croats and Slovenes, Official Gazette of the Kingdom of Yugoslavia No. 21/ 1929

98 The Constitution of the FPRY, Official Gazette of FPRY No. 10/1946. See in: Sirotković H., Margetić, L., Povijest država i naroda SFR Jugoslavije, Školska knjiga, Zagreb, 1988, pp. 378-379

99 Krbek, op. cit., note 75 , p. 238

100 Mihaljević, J., Ustavna uređenja temeljnih prava u Hrvatskoj 1946.-1974., Časopis za suvremenu povijest, Vol. 43, No. 1, Zagreb, 2011, p. 41

101 Krbek, op. cit., note 75, p. 238

102 E.g. According to Art. 25 of the Constitution of the FPRY, citizens were guaranteed freedom of conscience and freedom of religion; Art. 39, 40 and 41 further define the rights of citizens, their right to appeal and petition and compensation for damages 
according to the Law on the Nationalization of Private Economic Enterprises of 28 April 1948, all properties owned by foreign nationals, foreign institutions, or foreign private or public persons were nationalized and became state property. ${ }^{103}$ Foreign nationals had the same inheritance rights as nationals but only under the condition of reciprocity. ${ }^{104}$ There were also certain restrictions on employment in the bodies of state and public administration. Namely, according to Article 31 of the Law on Public Officials of 25 December $1957^{105}$, a Foreign Citizen could have been appointed for a civil servant only on the basis of the approval of the Federal or Republic Executive Council. A foreigner needed approval for the management of crafts or private crafts from the Council of the Economy with the approval of the Republican State Secretariat for Internal Affairs and Reciprocity. ${ }^{106}$

Foreigners generally had the freedom of movement in the territory of Yugoslavia and the right to change their place of residence as Yugoslav citizens. Thus, they could temporarily or permanently reside if they were granted a permit by the competent authority. If a foreigner was granted a permit for temporary or permanent residence, he had to be registered, and the records were kept by an administrative body of the district national committee responsible for internal affairs. ${ }^{107} \mathrm{In}$ addition, foreigners also had the right to social assistance and compensation for extraordinary damage. They also enjoyed special rights with regard to education and employment.

According to the Act on the Movement and Residence of Foreigners of 1980, a foreigner is considered to be any person who is not a citizen of The Socialist Federal Republic of Yugoslavia (hereinafter SFRY) or who, according to the provisions of the SFRY Citizenship Act of 1976, is not an SFRY citizen. ${ }^{108}$ According to the SFRY Constitution of 1974, it was determined that foreigners in Yugoslavia enjoyed the freedoms and rights of man and that they had other rights and duties as laid down by the law and international treaties. ${ }^{109}$ Consequently, Borković states

103 Bartoš, M; Nikolajevič, D. B., Pravni položaj stranaca: savremena shvatanja medunarodne prakse i prakse u FNRJ, Naučna knjiga, Beograd, 1951, p. 103-105

104 Art. 5 of the Law on Inheritance 1955, Official Gazette of SFRY No. 20/55

105 Art. 31 of the Law on Public Officials, Official Gazette of FPRY No. 53/57

106 See: Regulation on crafts and businesses, Official Gazette of FPRY No. 5/54; General Law on Craftsmanship Official Gazette of FPRY No. 49/1949; The Basic Law on Private Trades, Official Gazette of FPRY No. 39/1948, 40/1948

107 Ordinance of the Federal State Secretary for Internal Affairs, Official Gazette of FPRY No. 9/59; The Law on the Bodies of Internal Affairs, Official Gazette of FPRY No. 30/1956

108 The Law on Movement and Residence of Foreigners, Official Gazette of SFRY, No. 56/80, art. 1.); The Law on the Citizenship of SFRY, Official Gazette of SFRY No. 58/76

109 The Constitution of SFRY, Official Gazette of SFRY No. 9/1974 
that special efforts were made in Yugoslavia to ensure that foreigners were secured a decent human position. ${ }^{110}$

The issue of regulating the legal status of foreigners in SFR Yugoslavia was resolved by numerous laws concerning the legal situation of foreigners. Thus, foreigners who entered the SFRY on the basis of valid travel documents could move, reside, settle, set up their own associations, serve their personal name, acquire, and hold arms. ${ }^{111}$ Foreigners could exercise these rights only under the conditions prescribed by the Law on the movement and stay of foreigners of 1980 unless otherwise stipulated by an international treaty. In addition to the above-mentioned rights, foreigners could also exercise other rights established by other laws under reciprocal conditions. ${ }^{112}$

From the above, it may be concluded that the historical development of the legal position of foreigners evolved more and more towards the status of the citizen. From the Middle Ages, especially from the end of the 18th century to modern times, foreigners were almost equal with the citizens regarding so-called 'personal liberties and rights', but in principle, they were excluded of political rights, i.e., opportunities to participate in political life.

\section{CONCLUSION}

Considering the present-day problems Croatia is facing while trying to integrate regular immigrants into its social environment and legal framework, the aim of this contribution is to put the subject in its proper legal-historical context. The cross-section of the status of foreigners throughout Croatian history has shown that immigration has always been experienced as a challenge and a benefit at the same time. Although regular immigrants were usually observed from the prism

110 Borković, I., Upravno pravo, Informator, Zagreb, 1991, p. 118

111 Tomašević, P., Upravno pravo (posebni dio) - unutrašnji poslovi, Republički sekretarijat za unutrašnje poslove SR Hrvatske, Odjel za izdavačku djelatnost i dokumentaciju, Zagreb, 1989, p. 220

112 For example, according to the Art. 82 of Law on Basic Ownership Relations (Official Gazette of SFRY No. 6/80), it was stipulated that, subject to reciprocity, foreigners may be the holders of property rights on land and buildings acquired by inheritance on the territory of the SFRY, as well as SFRY citizens, unless otherwise specified by an international treaty. Also, according to the Art. 1 and 2 Law on Health Care Protection of Foreigners in Yugoslavia (Official Gazette of SFRY No. 2/1974, 5/1978) foreigners had the right to health care to be provided in the scope, in the manner and under the conditions under which health care is provided to SFRY citizens. Furthermore, a foreigner could establish a working relationship in SFRY under the conditions laid down in Art. 1 of the Law on Conditions for Establishing a Foreign Citizenship (Official Gazette SFRY No. 11/78, 64/89) and by the Law on Foreign Investments (Official Gazette of SFRY No. 77/88) invest resources in order to carry out economic and social activities in the SFRY 
of economic benefits, their social position and integration in the society proved troublesome.

The historical lessons teach us furthermore that successful integration is a two-way process that requires active contribution on both sides. On one hand, it implies the obligation of the recipient country to ensure a legal, social and economic framework which will enable the integration of foreigners, but on the other hand, it presupposes the commitment and adaptation of foreigners to legal standards and values of the recipient community. By tolerating the cultural, ethnic and religious peculiarities of different communities through their inclusion in the regional services as well as through gradual allocation of rights rather that invasive policy, the Romans demonstrated a way to integrate foreigners and stimulate them to accept values of domestic culture.

The current migration crisis exposed the poor implementation of the Croatian, often declarative, official migration policies, shifting their course towards security questions. Only recently, due to shortages in the labour market (especially in the field of tourism and construction) and the need for demographic renewal, immigration is slowly being identified as a tool to solve those deficiencies. The lessons from the historical overview make it quite clear that such an approach was always encouraged if it had a positive impact on the domestic community. Despite the medieval particularism, as a common feature, it can be observed that the prejudice and the negative attitudes towards foreigners were mitigated by the interests of the local municipalities. De facto throughout history, foreigners who were considered to perform beneficial and shortage occupations were invited to take up residence and settle down with their families in exchange for various privileges. They were granted legal protection before courts and other public bodies.

It proved, however, to be much easier to adjust the existing legal provisions, no matter how strict they were, than to enable the successful integration of foreigners because the economic, social and cultural components of migration flows have often been neglected. This implies that instead of applying ad hoc measures, the state should act proactively in order to create a tolerant environment. Since the migration policy in Croatia is reduced to the formal compliance to the EU requirements, the insights from the history should teach us to use the immigration potential of society more wisely instead of aligning it to the political interests to focus it on the benefits of the community and the foreigners itself. 


\section{REFERENCES}

\section{BOOKS AND ARTICLES}

1. András, M., Pannonia and Upper Moesia: A History of the Middle Danube Provinces of the Roman Empire, Routledge \& K. Paul, 1974

2. Balkovec, B., Izborno zakonodavstvo prve jugoslavenske države (1918. - 1941.), Časopis za suvremenu povijest, Vol. 48, No. 1, 2016, pp. 197-216

3. Balsdon, J., P., V., D., Romans and aliens, Duckworth, London, 1979

4. Baričević, V., Azil i imigracije: perspektiva rubnih zona unije i prava migranata, Političke analize Vol. 2, No. 5, 2011, pp. 30-35

5. Bartoš, M.; Nikolajevič, D. B., Pravni položaj stranaca: savremena shvatanja mecunarodne prakse i prakse u FNRJ, Naučna knjiga, Beograd, 1951

6. Berket, M. et. al. (eds.), Statut grada Trogira, Statuta et refomationes cicitatis Traguirii, Književni krug, Split, 1988

7. Beuc, I., Povijest država i prava na području SFRJ, Narodne novine, Zagreb, 1989

8. Birin, A., Pravni položaj stranaca u statutima dalmatinskih komuna, Zbornik - Odsjeka za povijesne znanosti Zavoda za povijesne i društvene znanosti Hrvatske akademije znanosti i umjetnosti (1330-7134), Vol. 20, 2002

9. Borković, I., Upravno pravo, Informator, Zagreb, 1991

10. Čepulo, D., Položaj i ustroj hrvatskih gradova prema Zakonu o uređenju gradskih općina iz 1881. godine, Hrvatska javna uprava: časopis za teoriju i praksu javne uprave, Vol. 2, No. 1, 2000, pp. 83-120

11. Čepulo, D., Statut Paške općine, Statuta Communitatis Pagi, Zagreb, 2011

12. Cvitanić, A. (ed.), Statut grada Splita, Statuta civitatis Spalati, II. dotjerano izdanje, Književni krug, Split, 1987

13. Cvitanić, A. (ed.), Hvarski statut, Satuta Communitatis Lesinae, Književni krug Split, 1991

14. Cvitanić, A. (ed.), Lastovski statut, Književni krug, Slit, 1994

15. Cvitanić, A., Iz dalmatinske pravne povijesti, Književni krug, Split, 2002

16. Cvitanić, A. (ed.), Brački statut, Drugo prošireno dopunjeno i dotjerano izdanje, Književni krug, Split, 2006

17. Dabinović, A., Statutarno pravo grada Zagreba, Mjesečnik: glasilo hrvatskoga pravničkoga družtva, No. 1-2, Zagreb, 1943, pp. 1-14

18. Derenčin, M., Tumač k obćemu austrijskomu gradjanskomu zakoniku, knjiga I, Nakladom Sveučilišne knjižare Albrechta i Fiedlera, Zagreb, 1880

19. Grubišić, S. (ed.), Knjiga statuta, zakona i reformacija grada Šibenika, Muzej grada Šibenika, Šibenik, 1982

20. Janeković Römer, Z., Stranac u srednjovjekovnom Dubrovniku: između prihvaćenosti i odbačenosti, Radovi Zavoda za hrvatsku povijest Filozofskoga fakulteta Sveučilišta u Zagrebu, Vol. 26, No. 1, 1993

21. Karlović, T., The Legal Status of Municipium Andautonia, in: Thür, G.; Lučić, Z. (eds.), Imperium und Provinzen (Zentrale und Regionen), Pravni fakultet Univerziteta u Sarajevu, 2006, pp. 51-74 
22. Karlović, T.; Milotić, I.; Petrak, M., Andautonia. An Example of Local Self-Government in Pannonia, Lex localis 13, 2015, pp. 35-48

23. Kasap, J., Legal Regulation of the Borrowing Institute in Medieval Croatian Statutory Law, Pravni vjesnik Pravnog fakulteta u Osijeku, Vol. 32, No. 1, 2016

24. Kolanović, J.; Križman, M. (eds.), Statuta Iadertina, Zadarski statut sa svojim reformacijama odnosno novim uredbama donesenima do godine 1563, Zadar 1997

25. Kosnica I., Državljanstvo i Opći gradanski zakonik u Kraljevini Hrvatskoj i Slavoniji od 1853. do 1879., Zbornik Pravnog fakulteta u Zagrebu, Vol. 63, No. 5-6, 2013, pp. 1143-1164

26. Kosnica, I., Gubitak državljanstva u Hrvatskoj i Slavoniji od Bachovog apsolutizma do raspada Monarhije, Pravni vjesnik, Vol. 29, No. 3-4, 2013, pp. 61-79

27. Kosnica, I., Utvrdivanje državljanstva u Hrvatskoj i Slavoniji 1849.-1880., Zbornik radova Pravnog fakulteta u Splitu, Vol. 51, No. 3., 2014., pp. 697-713

28. Krbek, I., Pravo javne uprave FNRJ (Osnovna pitanja i prava gradana), Birozavod, Zagreb, 1960

29. Lanović, M., Privatno pravo Tripartita za nastavne potrebe Pravničkog fakulteta, Tipografija d.d., Zagreb, 1929

30. Margetić, L, Strčić, P., Statut rapske komune iz 14. stoljeća = [Statut communis Arbae], Adamić, Rab, Grad Rab; Rijeka, 2004

31. Marinović, A.; Veselić, I. (eds.), Mljetski statut, Statut otoka Mljeta iz 1345. godine, Književni krug, Split- Dubrovnik, 2002

32. Mihaljević, J., Ustavna uređenja temeljnih prava u Hrvatskoj 1946.-1974., Časopis za suvremenu povijest, Vol. 43, No. 1, Zagreb, 2011, pp. 25-51

33. Milotić, I., Legal Status of Peregrini and their Communities in Roman Histira, in: Thür, G.; Lučić, Z. (eds.), Imperium und Provinzen (Zentrale und Regionen), Pravni fakultet Univerziteta u Sarajevu, 2006, pp. 97-127

34. Moatti, C., Translation, migration, and communication in the Roman Empire: three aspects of movement in history, Classical Antiquity, Vol. 25, No. 1, 2006, pp. 109-140

35. Mommsen, T., The Provinces of the Roman Empire from Caesar to Diocletian, Vol. 1, Macmillan \& co., London, 1909

36. Oliver, J., H., The Ruling Power: A Study of the Roman Empire in the Second Century after Christ through the Roman Oration of Aelius Aristides, Transactions of the American Philosophical Society, Vol. 43, No. 4, 1953, pp. 871-1003

37. Pavlović, M., Problem izjednačenja zakona u Kraljevini Srba, Hrvata i Slovenaca / Jugoslaviji, Zbornik Pravnog fakulteta u Zagrebu, Vol. 68, No. 3-4, 2018, pp. 493-523

38. Radić, Ž., Ratković, I., Položaj stranca u splitskom statutarnom pravu, Adrias: zbornik radova Zavoda za znanstveni i umjetnički rad Hrvatske akademije znanosti i umjetnosti u Splitu, No. 12, 2005

39. Raukar, T., Cives, habitatores, forenses u srednjovjekovnim dalmatinskim gradovima, Historijski zbornik, Vol. 29-30, Zagreb, 1976-1977

40. Raukar, T., Komunalna društva u Dalmaciji u XIV. stoljeću, Historijski zbornik, Vol. 33-34, Zagreb, 1980-1981 
41. Ristić, A., M., Pravni položaj stranaca, doctoral thesis, Beogradski univerzitet - Pravni fakultet, Beograd, 1934.

42. Sajfert, J., Naturalisation Procedures for Immigrants - Croatia, Eudo citizenship observatory, 2013

43. Saumagne, C., Le droit latin et les cités romaines sous l'empire: essais critiques, Sirey, 1965

44. Šeparović, Z. (ed.), Korčulanski statut, Statut grada i otoka Korčule iz 1214. godine, Književni krug, Split, 1987

45. Sherwin-White, A., H., The Roman Citizenship, Part II, Ch. X, Oxford, Clarendon Press, 1939

46. Sirotković H.; Margetić, L., Povijest država i prava naroda SFR Jugoslavije, Školska knjiga, Zagreb, 1988

47. Šoljić, A. et al. (eds.), Statut grada Dubrovnika, sastavljen 1272. godine, Državni arhiv u Dubrovniku, Dubrovnik, 2002

48. Soloman, E., Essai sur la condition juridique des étrangers dans les législations anciennes et le droit moderne, Paris, 1844

49. Taylor, T., S., Social Status, Legal Status and Legal Privilege, in: du Plessis, P., J. et al. (eds.), The Oxford Handbook of Roman Law and Society, 2016, pp. 349-361

50. Tomašević, P., Upravno pravo (posebni dio) - unutrašnji poslovi, Republički sekretarijat za unutrašnje poslove SR Hrvatske, Odjel za izdavačku djelatnost i dokumentaciju, Zagreb, 1989

51. Vuković, M., Opći gradanski zakonik: s novelama i ostalim naknadnim propisima, Školska knjiga, Zagreb, 1955

\section{EU LAW}

1. Consolidated versions of the Treaty on European Union and the Treaty on the Functioning of the European Union, OJ C 326, 26.10.2012

2. Regulation (EU) 2016/399 of the European Parliament and of the Council of 9 March 2016 on a Union Code on the rules governing the movement of persons across borders (Schengen Borders Code), OJ L 77, 23.3.2016

\section{LIST OF NATIONAL REGULATIONS, ACTS AND COURT DECISIONS}

1. Aliens Act (Official Gazette No 130/11, 74/13, 69/17, 46/18)

2. Croatian Citizenship Act (Official Gazette No 53/91, 70/91, 28/92, 113/93, 4/94, 130/11, $110 / 15)$

3. General Law on Craftsmanship (Official Gazette of FPRY No. 49/1949)

4. Law on associations, gatherings and arrangements (Official Gazette of the Kingdom of Yugoslavia No. 225/1931)

5. Law on Basic Ownership Relations (Official Gazette of SFRY No. 6/1980)

6. Law on Foreign Investments (Official Gazette of SFRY No. 77/1988)

7. Law on Health Care Protection of Foreigners (Official Gazette of SFRY No. 2/1974, 5/1978) 
8. Law on Inheritance (Official Gazette of SFRY No. 20/1955)

9. Law on Judges of Regular Courts of the Kingdom of Serbs, Croats and Slovenes (Official Gazette of the KSCS No. 295/1928)

10. Law on lawyers of the Kingdom of Serbs, Croats and Slovenes (Official Gazette of the Kingdom of Yugoslavia No. 21/ 1929)

11. Law on Movement and Residence of Foreigners (Official Gazette of SFRY No. 56/1980)

12. Law on Public Officials (Official Gazette of FPRY No. 53/57)

13. Law on the Bodies of Internal Affairs (Official Gazette of FPRY No. 30/1956)

14. Law on the Citizenship of SFRY (Official Gazette of SFRY No. 58/1976)

15. Law on Working Conditions for Foreigners (Official Gazette of SFRY No. 11/78, 64/89)

16. Migration Policy of the Republic of Croatia for the period 2013-2015 (Official Gazette No. 27/2013)

17. Ordinance of the Federal State Secretary for Internal Affairs (Official Gazette of FPRY No. 9/59)

18. Regulation on crafts and businesses (Official Gazette of FPRY No. 5/1954)

19. The Basic Law on Private Trades (Official Gazette of FPRY No. 39/1948, 40/1948)

20. The Constitution of The Socialist Federal Republic of Yugoslavia (Official Gazette of SFRY No. 9/1974)

21. The Constitution of The Federal People's Republic of Yugoslavia (Official Gazette of FPRY No. 10/1946)

22. The National Security Strategy of the Republic of Croatia (Official gazette No. 73/2017)

\section{WEBSITE REFERENCES}

1. Bužinkić, E., et al., Pregled pravnog i institucionalnog okvira za zaštitu stranaca u Hrvatskoj, Centar za mirovne studije, Zagreb, 2013, [https:/www.cms.hr/system/publication/pdf/39/ Pregled_pravnog_i_institucionalnog_okvira_za_za_titu_stranaca_u_Hrvatskoj.pdf] Accessed 03.04.2019

2. Migration and migrant population statistics, [https://ec.europa.eu/eurostat/statistics-explained/pdfscache/1275.pdf] Accessed 08.04.2019

3. Second European Union Minorities and Discrimination Survey, [https://www.cms.hr/system/ article_document/doc/487/fra-2017-eu-midis-ii-main-results_en.pdf] Accessed 08.04.2019

4. Trend se mijenja, u Hrvatsku se doseljavaju stranci, Večernji list, 11.2.2019, [https://www.vecernji.hr/premium/trend-se-mijenja-u-hrvatsku-se-doseljavaju-stranci-1300104] Accessed 09.04.2019

5. Za zapošljavanje stranaca u 2019. odobrena kvota od 65.100 dozvola, Točka na I - Medij za biznis, 21.12.2018,. [https://tockanai.hr/biznis/aktualno/zaposljavanje-stranacau-2019-19060/] Accessed 09.04.2019

6. Zbog predrasuda stranci u Hrvatskoj teško nadu posao, Nacional br. 1032, 18. 02. 2019, [https://www.nacional.hr/dossier-zbog-predrasuda-stranci-u-hrvatskoj-tesko-nadu-posao-2/] Accessed 09.04.2019 